\title{
The university endoscopy unit: The standard of care?
}

\author{
JORDAN GOLUBOV, MD, FRCPC, PAUI. C ADAMS, MD, FRCPC
}

ABSTRACT: In an attempt to investigate practice patterns of the modern gastrointestinal endoscopy unit, a survey was undertaken in 10 university-affiliated endoscopy units in three Ontario cities. The results showed that there was a wide range of premedications used, and that there was variation in the extent of patient monitoring, the method of endoscope sterilization and the degree of safety precautions. This survey provides information on the 'standard of care' in the university endoscopy unit and provides a framework for discussion for the establishment of guidelines for the modern gastrointestinal endoscopy unit. Can J Gastroenterol 1990;4(6):255-258

Key Words: Endoscopy, Monitoring, Safety

\section{L'unité d'endoscopie associée à l'université: Quelle est la qualité des soins?}

RESUME: Une enquête a été effectuée auprès de 10 unités d'endoscopie associées aux universités dans trois villes ontariennes, afin de déterminer les profils de la pratique dans l'unité d'endoscopie gastro-intestinale moderne. Les résultats révèlent qu'il existe une vaste gamme de prémédications ainsi qu'une variation dans l'étendue du monitorage des patients, la méthode de stérilisation de l'endoscope, et le degré des mesures de précaution. Cette étude fournit des données sur la qualité des soins dispensés dans les unités d'endoscopie des centres hospitaliers universitaires; elle fournit le cadre des discussions conduisant à l'élaboration des directives destinées au centre d'endoscopie gastro-intestinale d'aujourd'hui.

T enterology has become increasingly dominated by endoscopic procedures performed in outpatient and inpatient settings in modern endoscopic units
HE SPECIALTY OF GASTRO. within hospitals. The design and daily function of these units varies depending on personnel, experience, budget and other factors. With the increasing emphasis on quality of care evaluations
Department of Gastroenterology, University Hospital, University of Westem Ontario, London, Ontario

Correspondence and reprints: Dr Paul C Adams, Department of Medicine, University Hospital, University of Western Ontario, PO Box 5339, London, Ontario N6A 5A5

Received for publication March 23, 1990. Accepted June 22, 1990 and medicolegal issues, the onus is on the practising gastroenterologist to provide a level of safety and service which is comparable to the 'standard of care' available in the community. In an effort to define this standard further, practice patterns in 10 university-affiliated gastrointestinal endoscopy units were studied. This survey reviewed the procedures in 10 different endoscopy units with regard to pre-endoscopy assessment, patient monitoring and safety, and endoscopy hygiene.

\section{METHODS}

Ten endoscopy units in university teaching hospitals in three Ontario cities were visited. Data were obtained from senior nursing personnel in the endoscopy unit using a standard questionnaire. Data, therefore, were based on the clinical impression of these personnel, and no formal audit of the facilities or clinical outcomes was performed.

\section{RESULTS}

The survey revealed that esophagogastroduodenoscopy was the most common endoscopic procedure performed with a wide range of variability evident between individual units (Table 1). Similarly, there was considerable variability in the use of pre-endoscopy sedation (Table 2). A pre-endoscopy history was obtained by the nurse in all 


\section{TABLE 1 Patterns of care in university hospital endoscopy units}

\begin{tabular}{lcc}
\hline & \multicolumn{2}{c}{$\begin{array}{c}\text { Annual volume of } \\
\text { procedures }\end{array}$} \\
Procedure & Mean \pm SD & \multicolumn{1}{c}{ Range } \\
\hline EGD & $1815 \pm 339$ & $1018-4758$ \\
Colonoscopy & $686 \pm 71$ & $347-1094$ \\
$\begin{array}{l}\text { Flexible } \\
\text { sigmoidoscopy }\end{array}$ & $433 \pm 173$ & $114-1055$ \\
ERCP & $215 \pm 52$ & $88-575$
\end{tabular}

EGD Esophagogastroduodenoscopy: ERCP Endoscopic retrograde cholangiopancreatography

units and vital signs were recorded before and after the procedure. There was considerable variability in patient monitoring, availability of resuscitation equipment, and endoscopic hygiene (Table 3).

\section{DISCUSSION}

This survey of university endoscopy units was undertaken to provide information on the standard of care that is being provided in university affiliated endoscopy units. With the increasing use of endoscopy in community hospitals it was anticipated that a survey of the university affiliated units may provide useful information on the current 'standard of care'. No attempt was made to audit individual units formally and in no way do the authors assume that the level of care provided in a university

\section{TABLE 2}

Variation in preoperative medication among endoscopy units

\begin{tabular}{|c|c|}
\hline Procedure & Medication \\
\hline EGD & $\begin{array}{l}\text { Oral benzocaine spray, } \\
\text { diazepam, diazemule, } \\
\text { atropine, no systemic } \\
\text { medication }\end{array}$ \\
\hline Colonoscopy & $\begin{array}{l}\text { Diazepam, diazemule, } \\
\text { meperidine, pentazo- } \\
\text { cine, morphine, fen- } \\
\text { tanyl, buscopan, } \\
\text { glucagon, diphen- } \\
\text { hydramine }\end{array}$ \\
\hline ERCP & $\begin{array}{l}\text { Oral benzocaine spray, } \\
\text { diazepam, diazemule, } \\
\text { buscopan, glucagon, } \\
\text { diphenhydramine, } \\
\text { atropine }\end{array}$ \\
\hline
\end{tabular}

EGD Esophagogastroduodenoscopy: ERCP Endoscopic retrograde cholangiopancreatography affiliated endoscopy unit is more appropriate than that provided in a modern community hospital.

In no endoscopy unit is a routine assessment of all patients performed by a physician prior to an endoscopic procedure. In most cases, this would seem unnecessary as the physician would have done so in his office. However, some busy physicians will meet the patient for the first time in the endoscopy unit and a short history, particularly of concomitant medical illnesses and medications could enhance the safety of the upcoming procedure.

Parenteral medications are administered to the majority of patients undergoing endoscopic procedures. Previous surveys have reported the incidence of respiratory depression/ hypotension to be 0.19 to 0.64 per 1000 endoscopies $(1,2)$ although complications tend to be underestimated. Oxygen desaturation to less than $90 \%$ has been shown to occur in up to $29 \%$ of gastroscopies, $68 \%$ of colonoscopies and $44 \%$ of endoscopic retrograde cholangiopancreatographies at some point during the procedure (3-8). The process of endoscopic intubation alone has been suggested to contribute to this desaturation (9). Studies in healthy volunteers and smokers have shown a decrease in $\mathrm{P}_{\mathrm{a}} \mathrm{O}_{2}$ with meperidine and diazepam plus meperidine but not with diazepam alone (10-12).

The predictive value of pulmonary function studies on oxygen desaturation during endoscopic procedures has been reported in several studies. Patients with severe chronic obstructive lung disease $\left(\mathrm{FEV}_{1} / \mathrm{FVC}\right.$ less than $60 \%$ ) had a greater incidence of desaturation of more than $7 \%(4,13)$. However, even in the patients with oxygen desaturation there was no demonstrable increased morbidity or mortality. Whorwell et al (7) claimed that the $\mathrm{FEV}_{1} / \mathrm{FVC}$ was not predictive of a fall in $P_{\mathrm{a}} \mathrm{O}_{2}$ but the severity of the underlying obstructive airways disease was not documented. Lieberman et al (4) demonstrated an increased incidence of serious cardiac arrhythmias in patients with oxygen desaturation of greater than 7\%; however, another
TABLE 3

Variations in safety precautions among 10 university endoscopy units

\begin{tabular}{|c|c|}
\hline Procedure & $\begin{array}{l}\text { Number } \\
\text { of units }\end{array}$ \\
\hline $\begin{array}{l}\text { Pre-endoscopy history and } \\
\text { physical by physician }\end{array}$ & 0 \\
\hline $\begin{array}{l}\text { Pre-endoscopy history by } \\
\text { nurse }\end{array}$ & 10 \\
\hline \multicolumn{2}{|l|}{ Vital signs } \\
\hline Pre-endoscopy & 10 \\
\hline Post endoscopy & 10 \\
\hline \multicolumn{2}{|l|}{$\begin{array}{l}\text { Routine patient monitoring } \\
\text { during procedure }\end{array}$} \\
\hline Blood pressure/pulse & 0 \\
\hline ECG & 0 \\
\hline Continuous intravenous access & 2 \\
\hline Pulse oximetry & $0^{*}$ \\
\hline \multicolumn{2}{|l|}{$\begin{array}{l}\text { Routine patient monitoring } \\
\text { post procedure }\end{array}$} \\
\hline Blood pressure/pulse & 10 \\
\hline $\begin{array}{l}\text { Continuous recovery room } \\
\text { personnel }\end{array}$ & 7 \\
\hline \multicolumn{2}{|l|}{ Resuscitation equipment } \\
\hline CPR equipment on site & 4 \\
\hline CPR equipment off site & 4 \\
\hline $\begin{array}{c}\text { Pulmonary resuscitation } \\
\text { equipment on site }\end{array}$ & 6 \\
\hline \multicolumn{2}{|l|}{$\begin{array}{l}\text { Endoscope hygiene and } \\
\text { safety }\end{array}$} \\
\hline $\begin{array}{l}\text { Exclusively immersible } \\
\text { endoscopes } \\
\text { Uniform cleaning methods } \\
\text { for all endoscopes }\end{array}$ & 2 \\
\hline Immersible & 6 \\
\hline Nonimmersible & 4 \\
\hline $\begin{array}{l}\text { Selective cleaning for high } \\
\text { risk procedures }\end{array}$ & 5 \\
\hline
\end{tabular}

- Pending one unit; ECG Electrocardiograph monitor: CPR Cardiopulmonary resuscitation

study did not demonstrate any correla. tion between cardiac arrhythmias and $\mathrm{P}_{\mathrm{a}} \mathrm{O}_{2}$ (14). Although these studies, to this point, have been inconclusive about the relationship between sedation-induced respiratory depression, oxygen desaturation, and endoscopic complications, they emphasize the potential for cardiopulmonary complications during routine endoscopic procedures. Therefore, it is significant that over half of the units surveyed in this study did not have cardiopul. monary resuscitation equipment on site; patient monitoring during the procedure was uncommon; intravenous ac. cess was immediately available in the minority of procedures; and three units 
had no regular personnel in the recovery area. The use of routine pulse oximetry monitoring is gaining wider acceptance in the operating room and the intensive care unit, and one endoscopy unit surveyed has plans to use this technique to monitor patients during endoscopy. This will require further validation since no study has demonstrated that oximetry or electrocardiographic monitoring has altered the morbidity or mortality associated with endoscopic procedures. Guidelines on the monitoring of patients undergoing gastrointestinal endoscopic procedures by the American Society for Gastrointestinal Endoscopy state that in situations where the individualized needs of the patient indicate that more frequent assessment of cardiac rhythm, blood pressure or oxygen saturation will complement conventional clinical assessment, the use of noninvasive monitoring equipment is appropriate (15).

Universal precautions whereby all blood and secretions are regarded as potentially infectious has been recommended by most hospitals. However, in

ACKNOWLEDGEMENTS: Dr PC Adams is a Career Scientist of the Ministry of Health for Ontario and acknowledges the support of the Medical Research Council of Canada. The authors acknowledge the assistance of the personnel of the endoscopy units surveyed and the secretarial assistance of Cathy Brown.

\section{REFERENCES}

1. Mandelstam P, Sugawa C, Silvis S, et al. Complications associated with esophagogastroduodenoscopy and with esophageal dilatation. Gastrointest Endosc 1976;23:16-9.

2. Schiller K, Cotton PR, Salmon PR. The hazards of digestive fibre-endoscopy: A survey of the British experience. Gut 1972:13:1027.

3. Woods SD, Chung SC, Leung J, et al Hypoxia and tachycardia during endoscopic retrograde cholangiopancreatography; detection by pulse oximetry. Gastrointest Endosc 1989;35:523-5.

4. Lieberman DA, Wuerker CK, Katon RM. Cardiopuhnonary risk of esophagogastroduodenoscopy Gastroenterology 1985;88:468-72

5. Dark DS, Campbell DR, Wesselius LJ. practice, the endoscopy of a patient with known acquired immune deficiency syndrome (AIDS) or hepatitis B leads to an increase in anxiety of the endoscopy room personnel and often in alternative methods of sterilization of equipment, such as gas sterilization. Hepatitis B has been reportedly transmitted by an endoscope (16), although the risk of transmission is low (17-19). No case of AIDS has been clearly linked to endoscopic transmission of the human immunodeficiency virus (HIV). Only five of the 10 units surveyed employ a universal cleaning technique regardless of diagnosis. Meticulous physical cleaning of the endoscope is the most important part of the sterilization process $(20-22)$ but is not routinely performed in two of the units surveyed. Nine centres use a minimum of $10 \mathrm{mins}$ of chemical disinfection between procedures. Various disinfectants, primarily alcohols or glutaraldehyde preparations have been demonstrated to inactivate HIV and/or hepatitis B virus (23-26). The practices employed by seven units would satisfy the British Working Party recommendations for

Hypoxemia during esophagogastroduodenscopy and colonoscopy. Am Rev Respir Dis 1988;137:163. (Abst)

6. Fennerty MB, Earnest DL, Hudson PB, et al. Physiologic changes during routine endoscopy. Gastrointest Endosc 1988:34:214. (Abst)

7. Fennerty MB, Earnest DL, Hudson PB, et al. Physiologic changes during colonoscopy. Gastrointest Endosc 1990;36:22-5.

8. Gross JB, Long WB. Nasal oxygen alleviates hypoxemia in colonoscopy patients sedated with midazolain and meperidine. Gastrointest Endosc 1990;36:26-9.

9. Whorwell PJ, Smith CL, Foster KJ. Arterial blood gas tensions during upper gastrointestinal endoscopy. Gut 1976;17:797-800.

10. Zsigmond EK, Shively JG, Flynn K Diazepam and meperidine on arterial blood gases in patients with chronic obstructive pulmonary disease. J Clin Pharmacol 1975;15:464-9

11. Zsigmond EK, Flynn K, Martinez OA Diazepam and meperidine in healthy volunteers. J Clin Pharmacol 1976;14:377-81

12. Rozen P, Fireman Z, Gitat T. The causes of hypoxemia in elderly patients cleaning nonimmersible endoscopes, although only five of 10 units soak the entire immersible instrument between procedures as recommended by this group (22). The use of protective eyewear, masks, gloves and gowns are available in most endoscopic units but are not commonly used. A recent survey of endoscopy room practices in known AIDS cases in the US revealed that only $41 \%$ of personnel wore eye protection, $74 \%$ wore masks, and $87 \%$ wore gowns (27).

In summary, this survey has demonstrated that there is considerable variation in the safety procedures employed in university-affiliated endoscopy units. Safety of the patient and endoscopy room personnel should be of primary concern, but endoscopy room protocols are dependent on time between procedures, endoscopic inventory, hospital budgets and increased understanding of the transmission of infectious diseases. It is anticipated that with further awareness of local and international endoscopic safety procedures, guidelines can be established for the 'standard of care' in the endoscopy unit.

during endoscopy. Gastrointest Endosc 1982;28:243-6.

13. Rostykus PS, McDonald GB, Albert RK. Upper intestinal endoscopy induces hypoxemia in patients with obstructive pulmonary disease. Gastroenterology 1980;78:488-91.

14. Rozen P, Oppenheim D, Ratan J, et al. Arterial oxygen tension change in elderly patients undergoing upper gastrointestinal endoscopy. Scand ] Gastroenterol 1979;14:577-81.

15. American Society of Gastrointestinal Endoscopy. Monitoring of patients undergoing gastrointestinal endoscopic procedures. ASGE publication 1989. No. 1022.

16. Bimie GG, Quigley EM, Clements $G B$, et al. Endoscopic transmission of hepatitis B virus. Gut 1983;24:171-6.

17. Koretz RL, Camacho R. Failure of endoscopic transmission of hepatitis B. Dig Dis Sci 1979;24:21-4.

18. Moncada RE, Denes AE, Berquist KR. Inadvertent exposure of endoscopy patients to viral hepatitis $B$. Gastrointest Endosc 1978;24:231-2

19. Ayoola EA. The risk of type B hepatitis infection in flexible fibreoptic endoscopy. Gastrointest Endosc 1981;271:60-2

20. CDC guidelines for handwashing and 
hospital environmental control. Infect Control 1986;7:236-40.

21. Infection Control Guidelines. Health Protection Branch and Health Sevices Directorate, 3rd printing. Ottawa: Ministry of National Health and Welfare, 1987:80-9.

22. Cleaning and disinfection of equipment for gastrointestinal flexible endoscopy: Interim recommendations of a Working Party of the British Society of Gastroenterology. Gut
1988;29:1134-51.

23. Spire B, Montagnier L, Barre-Sinoussi $\mathrm{F}$, et al. Inactivation of lymphadenopathy associated virus by chemical disinfectants. Lancet 1984;i:899-901.

24. Resnick L, Veren K, Salahuddin SZ, et al. Stability and inactivation of HLTV-III/LAV under clinical and laboratory environments. JAMA 1986;255:1887-91.

25. Kobayashi H, Tsuzuki M, Koshimizu K, et al. Susceptibility of hepatitis B virus to disinfectants of heat. J Clin Microbiol 1984;20:214-6.

26. Bond WW, Favero MS, Petersen N], et al. Inactivation of hepatitis $B$ virus by intermediate to high level disinfectant chemicals. J Clin Microbiol 1983;18:535-8.

27. Raufman JP, Straus EW. Gastrointestinal endoscopy in patients with acquired immune deficiency syndrome: An evaluation of current practices. Gastrointest Endosc 1987;33:76-9. 


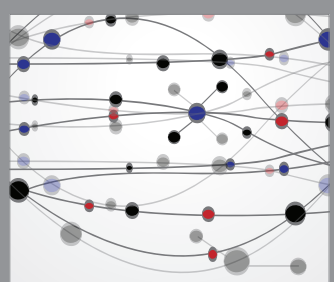

The Scientific World Journal
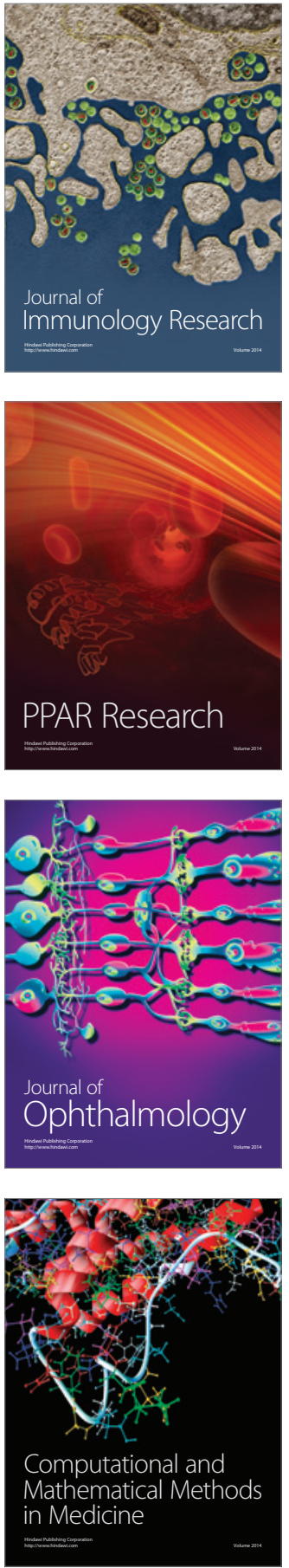

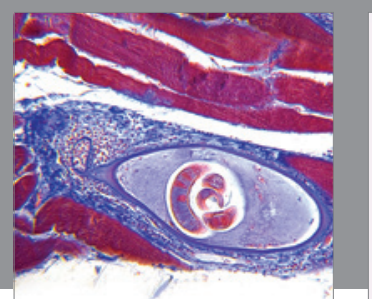

Gastroenterology Research and Practice

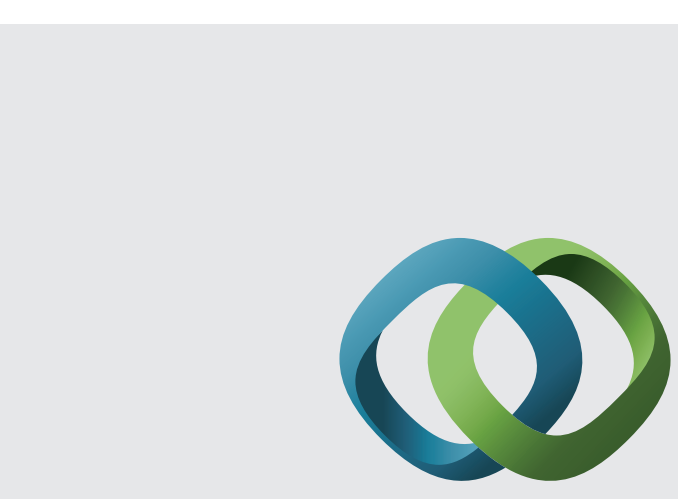

\section{Hindawi}

Submit your manuscripts at

http://www.hindawi.com
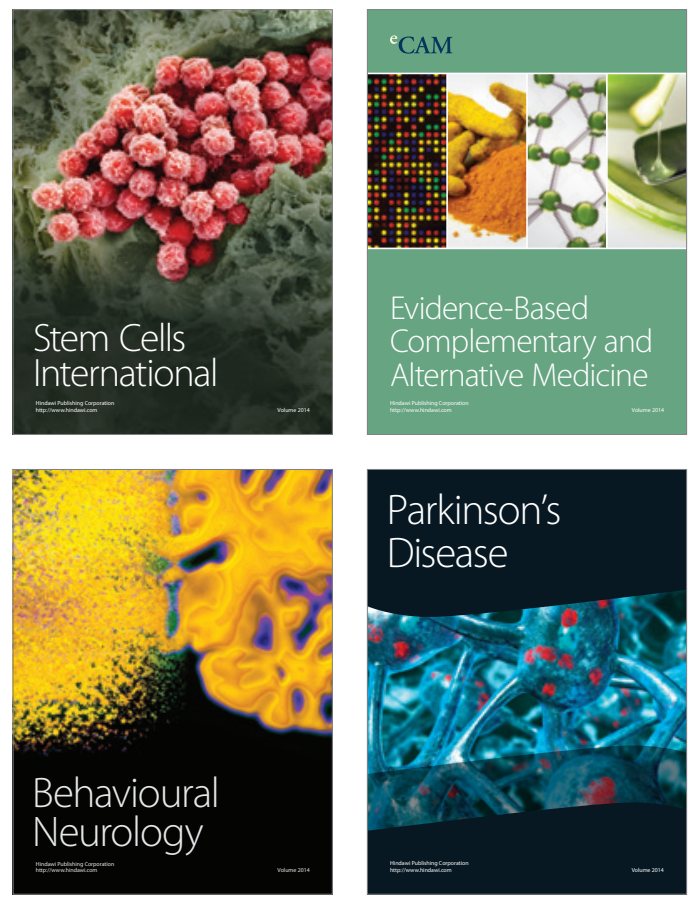
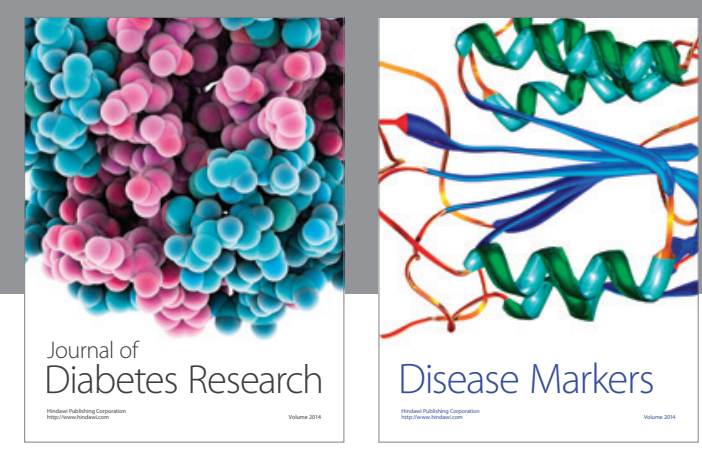

Disease Markers
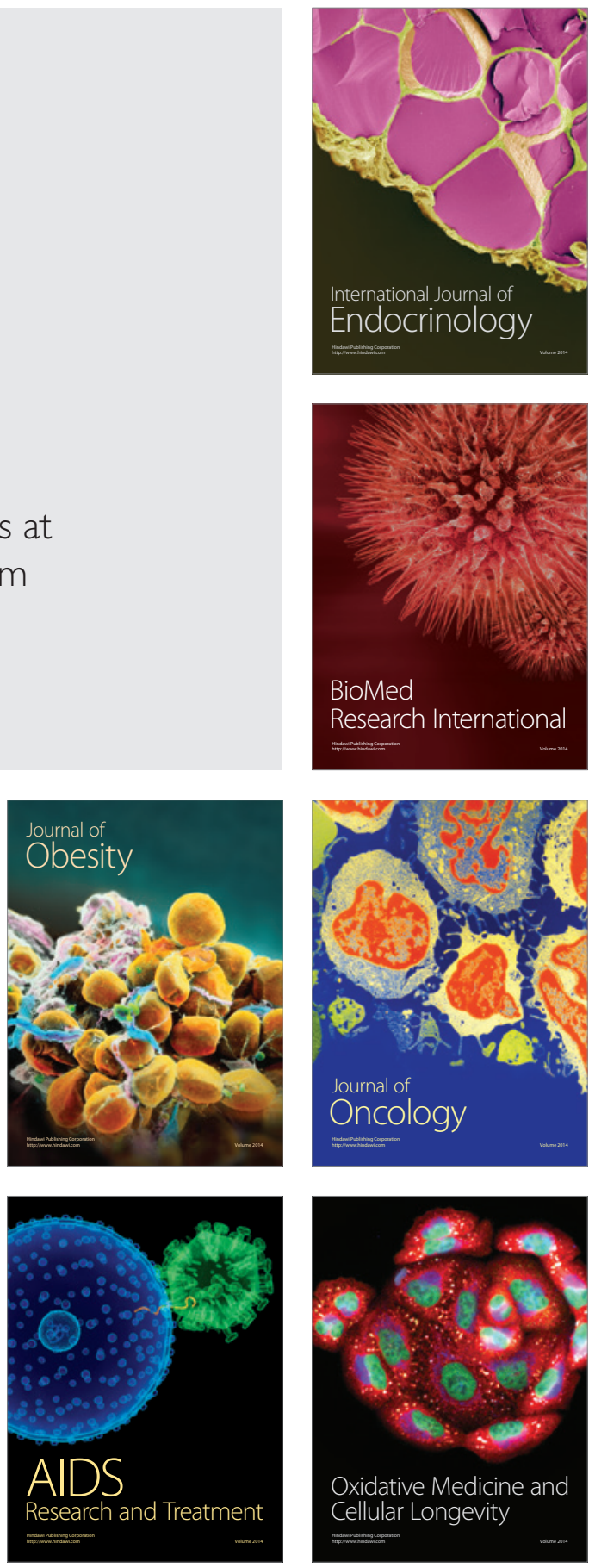